\title{
The Renewables Portfolio Standard in Texas: An Early Assessment
}

\author{
Ryan Wiser $^{\mathrm{a}}$ and Ole Langniss ${ }^{\mathrm{b} 1}$ \\ a Lawrence Berkeley National Laboratory, 1 Cyclotron Road, MS 90-4000, Berkeley, California USA, \\ Tel 510-486-5474, Fax 510-486-6996, rhwiser@lbl.gov \\ ${ }^{\mathrm{b}}$ German Aerospace Center, Institute of Technical Thermodynamics, Dept. Systems Analysis and \\ Technology Assessment, Pfaffenwaldring 38-40, D-70569 Stuttgart, Germany, Tel +49 7116862667 , \\ Fax +497116862783, ole.langniss@dlr.de
}

\begin{abstract}
Texas has rapidly emerged as one of the leading wind power markets in the United States. This development can be largely traced to a well-designed and carefully implemented renewables portfolio standard (RPS). The RPS is a new policy mechanism that has received increasing attention as an attractive approach to support renewable power generation. Though replacing existing renewable energy policies with an as-of-yet untested approach in the RPS is risky, early experience from Texas suggests that an RPS can effectively spur renewables development and encourage competition among renewable energy producers. Initial RPS targets in Texas will be well exceeded by the end of 2001 with $930 \mathrm{MW}$ of wind slated for installation this year. RPS compliance costs appear negligible with new wind projects reportedly contracted for under $3(\mathrm{US}) \phi / \mathrm{kWh}$, in part as a result of a $1.7(\mathrm{US}) \phi / \mathrm{kWh}$ production tax credit, an outstanding wind resource and an RPS that is sizable enough to drive project economies of scale. Obliged retail suppliers have been willing to enter into longterm contracts with renewable generators, reducing important risks for both the developer and the retail supplier. Finally, the country's first comprehensive renewable energy certificate program has been put into place to monitor and track RPS compliance.
\end{abstract}

\section{Introduction}

The renewables portfolio standard - a policy instrument that ensures that a minimum amount of renewable energy is included in the portfolio of electricity resources - has become increasingly popular in energy policy and research circles worldwide. The concept of an RPS is deceptively simple: it is a requirement for retail electricity suppliers (or, alternatively, electricity generators or consumers) to source a minimum percentage of their electricity needs from eligible renewable resources. To add flexibility and reduce the cost of meeting the requirement, tradable renewable energy certificates (REC) can be used to track and verify compliance.

The RPS has been recognized by some as perhaps the ideal way to encourage renewable energy development in competitive markets: the RPS aims to ensure that renewable energy targets are met at least cost and with a minimum of ongoing administrative involvement by the government (Rader and Norgaard 1996, Haddad and Jefferiss 1999, Berry and Jaccard 2001, Morthorst 2000). Detailed recommendations for the proper design of an RPS have been provided (Rader and Hempling 2001, Timpe et al. 2001, Mitchell and Anderson 2000,

\footnotetext{
${ }^{1}$ Senior authorship is shared.
} 
Price Waterhouse Coopers 1999, Schaeffer et al. 2000, Wiser and Hamrin 2000, Schaeffer and Sonnemans 2000, Espey 2001). Others have sought to project the costs and impacts of RPS requirements (e.g., Clemmer et al. 1999). Most of these recommendations and cost estimates have had to rely on theoretical principles, however, as practical experience in the application of the RPS has been limited. RPS policies have been established by legislation in 10 U.S. states, and in the countries of Australia, Austria, Belgium, Italy, and the United Kingdom, but little experience has been gained with the actual operation of the policy. ${ }^{2}$

Replacing existing renewable energy policies with an as-of-yet untested approach in the RPS is risky business. Some countries - including Germany, Spain, and Denmark - have had particularly good success in driving clean energy development with attractive "feed-in" tariffs. And experience in several U.S. states shows that a poorly designed RPS does little to increase renewable generation (Rader 2000). Nonetheless, emerging experience from the state of Texas demonstrates that a well-crafted and implemented RPS can deliver on its promise of strong and cost-effective support for renewable energy with a minimum of ongoing administrative intervention by the government. While experience even in Texas is limited, the Texas RPS has already fostered substantial renewable energy development, surpassing the achievements of any other RPS developed to date. This article describes the design of the Texas RPS and offers an early assessment.

\section{The Anatomy of the Texas RPS}

In 1999, the Texas government - under then governor George W. Bush established an RPS within the restructuring of the state's electricity market. $^{3}$ Detailed RPS regulations were subsequently established by the Texas Public Utilities Commission. ${ }^{4}$ The RPS is intended to encourage the development of new, environmentally beneficial resources and thereby reduce the environmental impacts of power production, and contribute to the development of rural areas by creating new renewable energy business opportunities. Resistance towards the RPS was significant among some sectors, large industrial customers especially. Helping to overcome this resistance was the fact that the RPS was only a small part of the overall restructuring legislation in which it was

Texas Details and RPS Timeline

STATE POPULATION

20 million (1999)

ANNUAL RETAIL ELECTRICITY SALES

305 million MWh (1998)

FUEL MIX

$39 \%$ coal, $49 \%$ natural gas, $11 \%$ nuclear, $1 \%$ renewable

TIMELINE

RPS Legislation May 1999

RPS Rulemaking Begins June 1999

RPS Rulemaking Ends December 1999

REC System Established July 2001

RPS Begins January 2002

RPS Ends January 2020

embedded, that the renewable and environmental advocacy communities argued forcefully and collaboratively for the RPS, and that public surveys showed overwhelming support for renewable energy.

${ }^{2}$ Denmark and Sweden have also both announced plans to move towards an RPS, though those plans are not finalised in formal legislation. The Netherlands is credited for being the first to develop a REC trading program (in 1998), but that program has not yet been used to meet mandatory renewable energy obligations under an RPS.

${ }^{3} \S 39.904$ of the Public Utility Regulatory Act (PURA).

${ }^{4}$ PUC Substantive Rules §25.173 Related to Goal for Renewable Energy. 
Table 1. The Texas RPS: Design Details

\begin{tabular}{|c|c|}
\hline Design Element & Design Details \\
\hline \multirow[t]{2}{*}{$\begin{array}{l}\text { Renewable energy } \\
\text { purchase obligations }\end{array}$} & $\begin{array}{l}\text { capacity targets of } 400 \mathrm{MW} \text { of eligible new renewables by } 2003,850 \mathrm{MW} \text { by } \\
2005,1400 \mathrm{MW} \text { by } 2007 \text {, and } 2000 \mathrm{MW} \text { by } 2009 \text { and through } 2019\end{array}$ \\
\hline & $\begin{array}{l}\text { annual energy-based purchase obligations beginning in } 2002 \text { and ending in } \\
2019 \text { derived based on capacity targets and average capacity factor of } \\
\text { renewable generation (initially set at 35\%) }\end{array}$ \\
\hline Obliged parties & $\begin{array}{l}\text { all electricity retailers in competitive markets ( } 80 \% \text { of total Texas load) share } \\
\text { the obligation based on their proportionate yearly electricity sales; publicly- } \\
\text { owned utilities must only meet the RPS if they opt-in to competition }\end{array}$ \\
\hline \multirow[t]{5}{*}{$\begin{array}{l}\text { Eligible renewable } \\
\text { energy sources }\end{array}$} & $\begin{array}{l}\text { new renewable power plants commissioned after September } 1,1999 \text { and all } \\
\text { renewable plants less than } 2 \mathrm{MW} \text { capacity, regardless of date of installation }\end{array}$ \\
\hline & $\begin{array}{l}\text { power production from solar, wind, geothermal, hydro, wave, tidal, biomass, } \\
\text { biomass-based waste products, and landfill gas are eligible }\end{array}$ \\
\hline & $\begin{array}{l}\text { purchases of renewable energy from plants larger than } 2 \mathrm{MW} \text { and built } \\
\text { before September } 1999 \text { may count towards a supplier's REC obligation, but } \\
\text { are not tradable }\end{array}$ \\
\hline & power must be located within or delivered to the Texas grid \\
\hline & $\begin{array}{l}\text { renewable energy sources that offset (but do not produce) electricity (e.g., } \\
\text { solar hot water, geothermal heat pumps), and off-grid and customer sited- } \\
\text { projects (e.g., solar) are also eligible }\end{array}$ \\
\hline \multirow{2}{*}{$\begin{array}{l}\text { Tracking and } \\
\text { accounting method }\end{array}$} & tradable renewable energy certificates with yearly compliance period \\
\hline & 3 month grace period after compliance period allowed for fulfilment \\
\hline Certificates & $\begin{array}{l}\text { issued on production, unit } 1 \mathrm{MWh}, 2 \text { years of banking allowed after year of } \\
\text { issuance, borrowing of up to } 5 \% \text { of the obligation in first } 2 \text { compliance } \\
\text { periods allowed, development of web-based certificates tracking system* }\end{array}$ \\
\hline Regulatory bodies & $\begin{array}{l}\text { Texas Public Utilities Commission establishes RPS rules and enforces } \\
\text { compliance; ERCOT Independent System Operator serves as REC trading } \\
\text { administrator }\end{array}$ \\
\hline Enforcement penalties & $\begin{array}{l}\text { the lesser of } 5(\mathrm{US}) \phi \text { or } 200 \% \text { of mean REC trade value in compliance period } \\
\text { for each missing KWh }\end{array}$ \\
\hline
\end{tabular}

* Some countries, notably Denmark, have considered establishing a price floor for RECs. No U.S. RPS has included this design feature.

The Texas RPS requires the installation of $2000 \mathrm{MW}$ of new renewable capacity by the year 2009 , in addition to preserving the $880 \mathrm{MW}$ of renewable energy already on line. ${ }^{5}$ This translates to about $3 \%$ of present electricity consumption. ${ }^{6}$ This goal is modest relative to the enormous potential for renewable energy development in Texas and the requirements of a truly "sustainable" electricity supply. ${ }^{7}$ Nonetheless, it represents a marked increase in renewable energy capacity in the state, and represents one of the most ambitious contemporary state renewable energy policies in the U.S. in terms of capacity additions.

\footnotetext{
${ }^{5}$ The level of the standard was established in a political setting, and was viewed at the time as being an aggressive but achievable target.

${ }^{6}$ Based on an assumed average capacity factor of $35 \%$. Assuming an average annual growth in demand of $3 \%$ this translates to a renewable energy share of $2.2 \%$ by 2009 .

${ }^{7}$ DOE (2000) estimates that wind power alone in Texas has the resource potential to deliver over $400 \%$ of the state's present electricity consumption. 
Intermediate new renewable capacity goals in Texas are $400 \mathrm{MW}$ by $2003,850 \mathrm{MW}$ by 2005 , $1400 \mathrm{MW}$ by 2007 and finally $2000 \mathrm{MW}$ by 2009 . These capacity goals are translated into megawatt-hour based energy requirements by using an average capacity factor of all eligible renewable plants; its value is initially set at $35 \%$ and will be adjusted over time based on actual plant performance.

Electricity retailers that serve markets open to competition are obliged to fulfil their portion (based on yearly retail electricity sales) of the renewable energy requirement by presenting RECs to the regulating authority on an annual basis. The obligation begins in 2002 and ends in 2019. The tradable RECs are issued for each MWh of eligible renewable generation located within or delivered to the Texas grid. With the exception of renewable power plants with a capacity smaller than $2 \mathrm{MW}$, which are eligible irrespective of their vintage, the REC trading program is restricted to facilities erected after September 1, 1999. A wide variety of renewable technologies are eligible. Table 1 summarizes the design features of the policy.

\section{Early Achievements: The Texas Wind Rush}

Renewable Energy Development. Though RPS obligations do not begin until 2002, the announcement of the RPS in 1999 and the subsequent completion of implementing regulations have already propelled Texas to one of the largest renewable energy markets in the United States. Consider:

- Over ten wind power projects - the largest of which is $275 \mathrm{MW}$ in size - totalling $930 \mathrm{MW}$ of capacity have been erected in the state thus far in 2001 or are planned for completion by the end of 2001.

- 12 new landfill gas projects with $44 \mathrm{MW}$ of total capacity have been announced.

- Approximately $50 \mathrm{MW}$ of hydropower renovations are planned in the near future.

- $2650 \mathrm{MW}$ of wind power projects have applied for grid access, providing an indication that growth in wind power capacity is unlikely to stall at the $930 \mathrm{MW}$ already well on its way to completion.

Given these results, it is evident that the RPS capacity targets for 2003 (400 MW) and 2005 (850 MW) may well be met several years early. Table 2 lists the expected RPS obligations of Texas retail electricity suppliers in 2002, and the wind contracts that have been signed to date (through October 2001). It should be noted that the commitments of the latter four utilities in the table are driven by customer preferences or utility resource planning decisions as opposed to RPS compliance.

Technology Selection and Cost Reductions. Wind power projects are the most competitive of all RPS-eligible renewable energy technologies in Texas at the moment, as untapped landfill gas resource opportunities are limited and hydro resources are nearly fully exploited. Solar generation as well as traditional forms of biomass energy are too costly in Texas to compete with wind power at this time. Most of the planned wind power plants are located in West Texas, where average annual wind speeds of $8 \mathrm{~m} / \mathrm{s}$ are common and capacity factors can exceed $40 \%$. The sizable purchase obligation under the RPS also allows wind projects to gain the economies of scale necessary for deep cost reductions. Combine this factor with the outstanding wind power resource and with the federal 1.7(US)cent/kWh production tax credit (PTC), and wind power projects in Texas are able to deliver power to the grid for less than $3(\mathrm{US}) \phi / \mathrm{kWh}$. 
Table 2. RPS Obligations and Wind Contracts for Retail Suppliers

\begin{tabular}{lcc}
\hline Electricity Supplier & $\begin{array}{c}\text { Approx. 2002 RPS } \\
\text { Obligation (MW) }\end{array}$ & $\begin{array}{c}\text { 2001 Wind } \\
\text { Contracts (MW) }\end{array}$ \\
\hline TXU & 170 & 353 \\
Reliant & 140 & 208 \\
AEP & 0 & 0 \\
Entergy & 0 & 0 \\
Excel-SPS & 40 & 80 \\
TNP & 2 & 3 \\
Enron & 15 & 130 \\
Other New Players & 33 & $?$ \\
\hline Austin & 0 & 80 \\
LCRA & 0 & 50 \\
San Antonio & 0 & 25 \\
El Paso & 0 & 1 \\
\hline TOTAL & $\mathbf{4 0 0} \mathbf{~ M W}$ & $\mathbf{9 3 0} \mathbf{~ M W}$ \\
\hline SOUrce: & &
\end{tabular}

Source: Updated through October 2001, and derived from Sloan (2001)

That the initial RPS targets are to be exceeded may therefore come as little surprise: wind power in Texas, with the PTC, is close to competing on purely economic grounds against new natural gas facilities, even with relatively low natural gas prices. With early overcompliance with the purchase standard and compliance costs that are at low levels given the competitive pricing offered by renewable generators, there are beginning to be calls for increasing the policy's renewable electric capacity goals. ${ }^{8}$

Long-Term Contracting. An equally important achievement under the Texas RPS is that obligated electricity suppliers have been willing to sign long-term (10-25 year) contracts for RECs and the associated electricity. Without long-term contracts, renewable energy developers are faced with the unenviable position of developing merchant renewable energy projects with highly uncertain returns (Wiser and Pickle 1997, Helby 1997, Langniss 1999). Similarly, electricity retailers risk not being able to procure the requisite number of RECs by year's end or only being able to procure credits at astronomical prices due to supply constraints or market manipulation.

Long-term contracts, on the other hand, ensure developers a stable revenue stream and access to low-cost financing, while delivering to electricity retailers a reliable stream of renewable electricity at stable prices. In fact, though renewable developers are often able to choose between REC-only sales and sales that combine the RECs and electricity, virtually all contracts to date have covered both the certificates and the electricity. This clearly demonstrates the importance of reducing revenue-risk on the part of developers. Retail electricity suppliers also have a strong incentive to bring renewable energy projects on line quickly under long-term contracts and with locked-in prices: with the PTC for wind power currently slated to expire at the end of 2001, REC prices may well rise in the future.

A final component of the long-term contracting process in Texas deserves mention. To shield risk on the retail suppliers' end that REC costs will increase and to reduce the risk that the supplier will fail to comply with the RPS, contract terms strongly penalize project construction lags and operational problems. This can be clearly seen in Table 3 , where we list the

\footnotetext{
${ }^{8}$ It should be noted, however, that the PTC is currently slated to expire after 2001. Though an extension of the policy appears likely, were it not extended RPS compliance costs in Texas would increase and other renewable technologies may better compete for a share of the RPS market with wind power.
} 
standard contract provisions for two utilities as expressed through RFP documents. ${ }^{9}$ Unlike competitive bidding situations in the U.K. under the Non-Fossil Fuel Obligation and in California under its system-benefits charge policy (Mitchell 2000, Bolinger et al. 2001), there is little incentive in Texas for developers to propose projects that do not have high probability of completion. ${ }^{10}$ In fact, such bidders will either be unsuccessful in garnering a contract or could face severe penalties if they were able to secure a contract. This may be an important advantage to the RPS approach.

With renewable electricity prices hovering around or below $3(\mathrm{US}) \phi / \mathrm{kWh}$ and numerous closely matched projects vying under each competitive solicitation, competition for costcompetitive renewable energy supply in Texas is working. ${ }^{11}$

Certificates Tracking System. A final milestone of achievement in Texas is the development of a web-based platform for the administration of the REC program. This platform - which will allow for the issuance, registration, trade, and retirement of RECs - was established in May 2001. The platform will facilitate tracking RPS compliance, but will not provide the "market making" function of a certificate exchange, as this function is to be the left to the private marketplace, as will REC brokering and financial markets.

Certificate-only trades have only just begun as RPS quotas do not apply until 2002 and a substantial amount of the initial certificates are bundled in long-term "electricity plus certificates" forward contracts through bilateral trades. As compliance obligations begin, trade of surplus certificates can be expected to increase and a secondary market may develop (Fabri 2001). A certificates exchange may also develop with time, though at present there are no announced plans for such an exchange; virtually all existing transactions have been bilateral ones that have included RECs and electricity, with a few brokered REC-only transactions. The price of certificates is currently expected to equal approximately 0.5 (US) $\phi / K W h$ during 2002, and this price has been realised in the few "off system" REConly trades that have occurred to date. ${ }^{12}$ With substantial oversupply of renewable energy relative to RPS obligations and with "electricity plus certificates" contracts at or below $3(\mathrm{US}) \phi / \mathrm{kWh}$, however, it is unclear whether even this REC price will be sustained. ${ }^{13}$

9 The security requirements imposed by retail suppliers favor renewable energy developers or development teams with strong financial backing.

${ }^{10}$ In both the U.K. and California, a substantial number of the new renewable energy projects that won bids under the Non-Fossil Fuel Obligation (UK) and the production-incentive auction (California) have never been developed. This result is partly due to the design of each policy, where a certain degree of speculative bidding by renewable energy developers has been allowed.

${ }^{11}$ The prices under these contracts are often fixed over the entire contract term, though a fixed annual escalation is sometimes applied. We note that the cost-competitive pricing offered relies on the availability of the PTC.

${ }^{12}$ As of mid-September 2001, at least two small, brokered REC-only trades have been completed (Fabri 2001). Both trades were brokered by Natsource LLC and in both cases the REC purchaser is not a retail supplier with RPS compliance obligations (i.e., they are off-system trades). Both trades are also one-time purchases. The first trade, a sale of just under $1000 \mathrm{MWh}$ of RECs that traded at $0.6(\mathrm{US}) \phi / \mathrm{kWh}$, went to a European buyer interested in reselling the RECs in their own market. The second trade - less than $500 \mathrm{MWh}$ of RECs at $0.5(\mathrm{US}) \phi / \mathrm{kWh}$ - went to an energy company for public relations reasons.

${ }^{13}$ Three forces that may keep prices in this range are: (1) the potential for off-system trades such that REC demand (even if occurring outside of the Texas RPS) catches up with REC supply, (2) the possibility of market power in the REC market, with just a few utilities initially contracting for a majority of the RECs in circulation, and (3) reduced natural gas prices, which increases the relative, LBNL-49107.doc 
Table 3. Elements of Typical Renewable Energy Contracts

\begin{tabular}{|c|c|c|}
\hline Proposed Provisions & TXU & SPS \\
\hline Requested product & RECs or RECs \& associated energy & RECs or RECs \& associated energy \\
\hline Quantity & $\begin{array}{l}\text { approx. } 500,000 \mathrm{MWh} / \mathrm{yr} \text { total; } \\
1,000 \mathrm{MWh} / \mathrm{yr} \text { minimum quantity of } \\
\text { individual proposals to minimize } \\
\text { administrative burdens }\end{array}$ & $\begin{array}{l}\text { approx. } 123,560 \mathrm{MWh} / \mathrm{yr} \text { total; no } \\
\text { minimum quantity of individual } \\
\text { proposals }\end{array}$ \\
\hline Term & $\begin{array}{l}10 \text { years*; start date must be before } \\
2002\end{array}$ & $\begin{array}{l}15 \text { years; start date must be before } \\
2002\end{array}$ \\
\hline $\begin{array}{l}\text { Options for term } \\
\text { extension }\end{array}$ & $\begin{array}{l}\text { buyer may opt twice for } 4 \text { additional } \\
\text { years }\end{array}$ & none ${ }^{* *}$ \\
\hline After termination & $\begin{array}{l}\text { option to purchase facility at fair } \\
\text { market value }\end{array}$ & no provisions \\
\hline Annual amount & $\begin{array}{l}\text { fixed over the contract term; must } \\
\text { sell all electric production including } \\
\text { excess amount to buyer (if bid for } \\
\text { RECs and associated energy) }\end{array}$ & $\begin{array}{l}\text { fixed over the contract term; must } \\
\text { sell all electric production including } \\
\text { excess amount to buyer (if bid for } \\
\text { RECs and associated energy) }\end{array}$ \\
\hline Contract purchase price & $\begin{array}{l}\text { one price for the entire term; price } \\
\text { may vary for each option period }\end{array}$ & fixed by contract for every year \\
\hline $\begin{array}{l}\text { Definition of excess } \\
\text { amount }\end{array}$ & $>105 \%$ of contracted amount & $>110 \%$ of contracted amount \\
\hline $\begin{array}{l}\text { Purchase price for } \\
\text { excess amount }\end{array}$ & $50 \%$ of the usual contract price & $50 \%$ of the usual contract price \\
\hline $\begin{array}{l}\text { Penalty for under- } \\
\text { performance }\end{array}$ & $\begin{array}{l}5(\mathrm{US}) \phi / \mathrm{kWh} \text { payment for consistent } \\
\text { production less than annual amount }\end{array}$ & $\begin{array}{l}5(\mathrm{US}) \phi / \mathrm{kWh} \text { payment for consistent } \\
\text { production less than annual amount }\end{array}$ \\
\hline $\begin{array}{l}\text { Security required once a } \\
\text { project is short-listed for } \\
\text { contract consideration }\end{array}$ & $\begin{array}{l}\text { irrevocable letter of credit or } \\
\text { comparable for } 2 \text { years, } \\
0.5(\cup S) \phi / k W h \text { based on yearly } \\
\text { production }\end{array}$ & $\begin{array}{l}\text { irrevocable letter of credit or } \\
\text { comparable for } 2 \text { years, } \\
0.5(\cup S) \phi / k W h \text { based on yearly } \\
\text { production }\end{array}$ \\
\hline $\begin{array}{l}\text { Security required once a } \\
\text { purchase contract has } \\
\text { been finalization }\end{array}$ & $\begin{array}{l}0.5(\mathrm{US}) \phi / \mathrm{kWh} \text { based on yearly } \\
\text { production to cover under- } \\
\text { performance penalties, etc. }\end{array}$ & $\begin{array}{l}5(\mathrm{US}) \phi / \mathrm{kWh} \text { based on yearly } \\
\text { production to cover under- } \\
\text { performance penalties, etc. }\end{array}$ \\
\hline $\begin{array}{l}\text { Construction } \\
\text { requirements }\end{array}$ & $\begin{array}{l}\text { projects only selected if have } \\
\text { demonstrated business and } \\
\text { technical expertise to deliver on } \\
\text { time and within contract } \\
\text { requirements }\end{array}$ & $\begin{array}{l}\text { projects only selected if high } \\
\text { probability of timely construction; } \\
\text { monthly progress reports; penalties } \\
\text { for not meeting construction } \\
\text { milestones }\end{array}$ \\
\hline Operation requirements & $\begin{array}{l}\text { adequate staff for operation } \\
\text { required; transmission and ancillary } \\
\text { services handled by buyer if RECs } \\
\& \text { associated energy; timely } \\
\text { maintenance and status updates }\end{array}$ & $\begin{array}{l}\text { joint development of operating } \\
\text { procedures; timely maintenance } \\
\text { and status updates; minimum } \\
\text { performance requirement }(>90 \% \\
\text { availability) }\end{array}$ \\
\hline
\end{tabular}

Source: Public requests for proposal documents from two Texas utilities, TXU and SPS. We note that these are proposed contract requirements. Actual contracts may differ somewhat.

incremental cost of renewable energy. REC banking may also support higher REC trading values, as RECs can have value in future compliance periods. 


\section{Success Factors: The Devil is in the Details!}

Though there are numerous ways of effectively structuring an RPS, certain fundamental policy design principles must be followed if an RPS is to function at low cost and with maximum impact. Of particular importance is that the RPS must provide sufficient confidence to renewable energy developers and retail electricity suppliers to ensure long-term, least cost investment in renewable energy facilities. As shown in Text Box 1, a number of other state RPS' have failed or appear likely to fail in this respect. The early successes of the Texas RPS, on the other hand, can be largely attributed to several positive design and implementation features of the policy.

Strong Political Support and Regulatory Commitment. Strong legislative support for the RPS and a committed Public Utilities Commission charged with implementing the RPS ensured that the policy's design details were carefully crafted. ${ }^{14}$ Such strong support and commitment have not been evident in several other U.S. states' RPS policies, where implementation details are often poorly designed and languish in uncertainty.

Predictable Long-Term Purchase Obligations that Drive New Development and Economies of Scale. The size and structure of the Texas RPS ensures that new renewable development will be required to meet suppliers' REC obligations beginning in 2002 . The standard increases gradually over time, and offers developers adequate time to develop their projects before the REC obligation begins. The standard applies to the majority of retail electricity load in Texas, ensuring a degree of competitive neutrality. Capacity targets are translated into performance-based renewable electricity purchase obligations to encourage high levels of project performance. The target, at $2000 \mathrm{MW}$ in 2009, continues at the same level for an additional 10 years, ensuring projects adequate time to recover their capital costs. Intermediate targets are sizable enough to allow large-scale renewable energy development and, through economies of scale, reduce costs dramatically.

Credible and Automatic Enforcement. Retail electricity suppliers that fail to meet their RPS obligations are faced with sure and strong penalties: the penalty for non-compliance is set to the lesser of 5 (US) cents per missing $\mathrm{kWh}$ or $200 \%$ of the mean trade value of certificates in the compliance period. It does not pay to delay compliance, and retail suppliers have ensured their ability to comply by inserting penalty provision in their renewable energy contracts so projects come online on schedule and operate within specifications. The strong political commitment to the policy and an effective enforcement mechanism provides the support necessary to support low-cost, long-term contracting. While the $5(\mathrm{US}) \phi / \mathrm{kWh}$ penalty also acts as a cost cap to the policy, there is no evidence that this cap will be reached.

Flexibility Mechanisms. Though enforcement of non-compliance will be swift and sure, adequate flexibility is build into the policy to ensure that suppliers have every opportunity to meet their obligations in a cost-effective fashion. A yearly compliance period, a 3-month "true up" period, REC banking for 2 years after the year of issuance, a 6-month early compliance period in $2001,{ }^{15}$ and allowance for limited REC borrowing all offer the necessary flexibility. Given the degree of over-compliance likely at least in the initial years of the Texas RPS, it appears as if REC banking in particular will be commonplace.

Certificate Trading. Though certificate trading may not be essential for the effective design of a state RPS, and little trading has yet taken place in the Texas market, a REC system

\footnotetext{
${ }^{14}$ One reason for this strong commitment to the success of the policy is that earlier polling in Texas showed surprising strong support for developing renewable energy among the state's residents.

15 Though REC purchase obligations do not begin until 2002, to help ensure RPS compliance, RECs generated during the later half of 2001 can be used to meet 2002 compliance obligations.
} 
should ease compliance demonstration and tracking, improve liquidity in the market, provide additional flexibility to suppliers, and lower the overall cost of policy compliance. The Texas RPS features the first such REC tracking system in operation in the United States.

Favorable Transmission Rules and Siting Processes. Though the RPS is the principal driver in the growth of the Texas renewable energy market, other features of the Texas market facilitate RPS compliance at low cost and with limited hurdles. First, with a worldclass wind resource and limited wind power siting constraints, wind projects can be built in large increments, capturing cost reductions due to economies of scale. Second, though severe transmission capacity limits may initially constrain wind development in West Texas, the state has established favorable transmission planning and costing approaches that will benefit renewable generation and that may prevent ongoing congestion. ${ }^{16}$

Production Tax Credit. Finally, the federal PTC for wind projects also significantly reduces RPS compliance costs. Moreover, the fact that the PTC is currently only available for plants erected before the end of $2001,{ }^{17}$ and that REC prices may increase in the future if the PTC is not extended, provides every incentive for early RPS compliance and long term contracting between retail electricity suppliers and renewable energy projects.

\footnotetext{
${ }^{16}$ Texas is aggressively strengthening its transmission system and, as in many European countries, grid expansion costs are paid by Texas electricity customers rather than by the power plant operator. Moreover, fees to recover the embedded costs of existing and new transmission infrastructure are placed on electricity consumers based on a flat fee, or postage stamp approach independent of the location of production or consumption (congestion costs will also be charged). A standard interconnection process has been established. Scheduling rules and requirements for intermittent generation are also relatively favorable.
}

${ }^{17}$ The PTC may be extended, however, as wide bipartisan support for the policy has been achieved. 


\section{Text Box 1. Design Features of Other U.S. RPS Policies}

Ten U.S. states have recently implemented renewable energy purchase requirements, often (but not always) as a component of electricity reform: Arizona, Connecticut, Maine, Massachusetts Nevada, New Jersey, New Mexico, Pennsylvania, Texas, and Wisconsin. Though some successes are beginning to emerge from Arizona and Wisconsin, and there is much hope for the standards in Massachusetts, Nevada, and New Jersey, few of these policies have been operable for more than a year and several have not yet begun.

More importantly, the RPS' in several of these states do not contain the same strong provisions as those established in Texas, and may do little to instil confidence in the renewable energy industry. While we do not detail the RPS designs of each state here, a few illustrative examples show the importance of careful RPS design (see Rader 2000 for more information).

The most important problems experienced in U.S. RPS design include:

- Inadequate attention to the relationship between the renewable energy purchase requirement and eligible renewable energy sources. For example, Maine established a 30\% RPS. Though this represents the highest RPS in the world, eligible resources include the vast majority of renewable energy and high-efficiency natural gas cogeneration in the New England region. Existing supply therefore far exceeds the standard itself. As a result, the RPS will do nothing to support new renewable energy development, and is unlikely to do much to support existing supply either.

- Selective application of the purchase requirement. Several U.S. states only apply the RPS to a small segment of the state's market, muting the potential impacts of the policy. For example, in Connecticut the utilities that deliver energy to customers that do not switch to a new electricity supplier are exempt from the purchase requirement. Not only does this approach violate the principle of competitive parity, it also ensures that the RPS will have only a marginal impact, as the vast majority of customers have shown no interest in switching suppliers.

- Uncertain purchase obligation or end-date. Another common concern is the uncertainty in the size of the purchase standard and its end-date in some U.S. states. In Maine, for example, the RPS is to be reviewed every five years. In Connecticut and Massachusetts, when and how the RPS will end is simply unclear.

- Insufficient enforcement of the purchase requirement. Without adequate enforcement, retail electricity suppliers will surely fail to comply with the RPS. In this environment, renewable energy developers will have little incentive to build renewable energy plants. At best, the enforcement rules of a number of U.S. RPS policies are vague in their application: these include those policies in Connecticut, Maine, and Massachusetts.

Though of substantially lesser importance, still other states have failed to implement a renewable energy certificate system for easily tracking and monitoring compliance with the RPS. States in this category include Maine, Connecticut, New Mexico, Pennsylvania.

\section{Conclusions}

Though the RPS has been hailed as the leading, "market-based" approach to supporting renewable generation - and several countries have opted to replace traditional policy mechanisms with this new approach - little experience exists on RPS implementation. What is becoming clear from the little experience that does exist is that, like any renewable energy policy, an RPS can be designed well or it can be designed poorly. Experience in several U.S. states and European countries shows that inadequate purchase obligations, overly broad 
renewable energy eligibility guidelines, unclear regulatory rules, insufficient enforcement, and wavering political support can all doom an RPS to certain failure.

And yet the Texas policy shows that an RPS, if properly designed and carefully implemented, can deliver on its promise of offering a low-cost, flexible, and effective support mechanism for renewable energy. The Texas wind rush is likely to drive half of all wind development in the United States in 2001, and there is some evidence that this rapid development path will continue for some years to come.

To be sure, this wind power boom is not solely an outgrowth of an effective RPS policy. A developing customer-driven market for green power and the wind power plans of electricity utilities not subject to RPS requirements have also driven some of the development. The federal PTC for wind, favorable transmission rules, and an outstanding wind resource have additionally played important roles. Such complementary policy and market mechanisms are nearly always essential for effective renewable energy deployment. In fact, it should be reemphasized that the Texas RPS is largely supporting the development of the lowest cost renewable energy technology - wind power. Other U.S. states have developed additional policies to ensure a diversity of renewable energy supply options.

Nonetheless, it can be said with near certainty that, given previous development plans, the major driver in the resurgence of wind energy development in Texas has been the state's aggressive RPS. Other countries and U.S. states would be well served to study carefully the successful efforts of RPS design in Texas.

Perhaps the most intriguing element of the Texas RPS is that it obliged electricity suppliers to deal with wind power and other renewable energy sources on a large scale and in a proactive fashion. Growing industry confidence in these technologies seems unavoidable, and electricity suppliers are beginning to realize that sizable wind projects in Texas, with the PTC, are sometimes able to compete on an equal footing with other, more traditional generating sources. While the $2000 \mathrm{MW}$ purchase obligation established by the RPS will provide a good footing for initial development, a maturing wind industry able to compete at or near the cost of natural gas will surely offer more substantial market opportunities over the long term.

\section{Acknowledgements}

Work reported here was funded by the German Aerospace Center and by the Assistant Secretary of Energy Efficiency and Renewable Energy, Office of Power Technologies of the U.S. Department of Energy under Contract No. DE-AC03-76SF00098. We particularly thank Jack Cadogan and Larry Mansueti of the U.S. Department of Energy for their support of this work. For providing useful information or helpful review comments, we also thank Mark Bolinger (Berkeley Lab), Mark Kapner (Austin Energy), Reid Buckley (Orion Energy LLC), Nicole Fabri (Natsource LLC), David Hurlbut (Texas PUC), Brian Evans (RES Inc.), Henry Eby (LCRA), Russel Smith (TREIA), Steve Palomo (U.S. DOE), Cathy Ghandehari (U.S. DOE), Doug Seiter (U.S. DOE), Mark MacLeod (Environmental Defense), Lars Nilsson (IMES), Peter Helby (IMES), and Lori Bird (National Renewable Energy Laboratory).

\section{References}

Berry, T., Jaccard, M., 2001. The Renewable Portfolio Standard: Design Considerations and an Implementation Survey. Energy Policy, 29(4): 263-277

Bolinger, M., Wiser, R., Milford, L., Stoddard, M., Porter, K. 2001. Clean Energy Funds: An Overview of State Support for Renewable Energy. LBNL-47705. Berkeley, Calif.: Lawrence Berkeley National Laboratory. 
Clemmer, S., Nogee, A., Brower, M. 1999. A Powerful Opportunity: Making Renewable Electricity the Standard. Cambridge, Mass.: Union of Concerned Scientists.

Department of Energy (DOE). 2000. Database. Texas Wind Resources. http://www.eren.doe.gov/state_energy/tech_wind.cfm?state=tx

Espey, S., 2001. Renewables Portfolio Standard: A Means for Trade with Electricity from Renewable Energy Sources? Energy Policy, 29(7): 557-566

Fabri, N. 2001. NatSource. Personal communication. September.

Haddad, B., Jefferiss, P. 1999. Forging Consensus on National Renewables Policy: The Renewables Portfolio Standard and the National Public Benefits Trust Fund. The Electricity Journal, 12(2): 68-80.

Helby, P. 1997. "The Devil is in the Detail." Windpower Monthly, 13 (11): 32

Langniss, O. (ed.). 1999. Financing Renewable Energy Systems. ISBN 3-98 04322-6-2. Kiel.

Mitchell, C., 2000. The England and Wales Non-Fossil Fuel Obligation. History and Lessons. Annual Review of Energy and the Environment, 25(1): 285-312.

Mitchell, C., Anderson, T. 2000. The Implications of Tradable Green Certificates for the UK. ETSU: TGC (K/BD/00218).

Morthorst, P.E., 2000. The Development of a Green Certificate Market. Energy Policy, 29(15): 1085-1094.

Price Waterhouse Coopers. 1999. Organization of RE Market and Trading of Green Certificates. Prepared for the Danish Energy Agency.

Rader, N. 2000. The Hazards of Implementing Renewables Portfolio Standards. Energy and Environment, 11(4): 391-405.

Rader, N., S. Hempling. 2001. The Renewables Portfolio Standard: A Practical Guide. Prepared for the National Association of Regulatory Utility Commissioners.

Rader, N., Norgaard, R. 1996. Efficiency and Sustainability in Restructured Electricity Markets: The Renewables Portfolio Standard. The Electricity Journal, 9(6):37-49.

Schaeffer, G.J., Boots, M.G., Mitchell, C., Anderson, T., Timpe, C. Cames, M. 2000. Options for Design of Tradable Green Certificate Systems. ECN-C-00-032.

Schaeffer, G.J., Sonnemans, J. 2000. The Influence of Banking and Borrowing Under Different Penalty Regimes in Tradable Green Certificate Markets: Results from an Experimental Laboratory Experiment. Energy and Environment, 11(4): 407-422.

Sloan, M. 2001. The Texas Model for Renewable Energy Policy. Presentation to Windpower 2001. Washington, D.C.: American Wind Energy Association.

Timpe, C., Bergmann, H., Klann, U., Langniss, O. Nitsch, J., Cames, M., Voß, J. 2001. Realisation Aspects of a Quota Model for Electricity from Renewable Energy Sources (in German). Study commissioned on behalf of the Ministry of Environment and Traffic BadenWürttemberg. Stuttgart. 
Wiser, R., Hamrin, J., 2000. Designing a Renewables Portfolio Standard: Principles, Design Options, and Implications for China. Report prepared for the China Sustainable Energy Project. San Francisco, California: Center for Resource Solutions.

Wiser, R., Pickle. S. 1997. Financing Investments in Renewable Energy: The Role of Policy Design and Restructuring. LBNL-39826. Berkeley, Calif.: Lawrence Berkeley National Laboratory. 